\title{
Genetics in the advanced heart failure population - University Hospital Centre Zagreb experience
}

\author{
Olvo Planinc *, \\ DDubravka Šipuš, \\ (CNina Jakuš, \\ DDora Fabijanović, \\ (DBoško Skorić, \\ (DHrvoje Jurin, \\ (1) Jure Samardžić, \\ (1) Jana Ljubas, \\ - Marijan Pašalić, \\ DDaniel Lovrić, \\ - CFran Borovečki, \\ CMaja Čikeš, \\ DDavor Miličić
}

University of Zagreb School of Medicine, University Hospital

Centre Zagreb, Zagreb, Croatia

\begin{abstract}
KEYWORDS: genetics, advanced heart failure, cardiomyopathy, phenotype.
CITATION: Cardiol Croat. 2021;16(1-2):27. | https://doi.org/10.15836/ccar2021.27

*ADDRESS FOR CORRESPONDENCE: Ivo Planinc, Klinički bolnički centar Zagreb, Kišpatićeva 12, HR-10000 Zagreb, Croatia. / Phone: +385-98-525449 / E-mail: ivo.planinc@gmail.com

ORCID: Ivo Planinc, https://orcid.org/0000-0003-0561-6704 • Dubravka Šipuš, https://orcid.org/0000-0002-5631-0353 Nina Jakuš, https://orcid.org/0000-0001-7304-1127 • Dora Fabijanović, https://orcid.org/0000-0003-2633-3439 Boško Skorić, https://orcid.org/0000-0001-5979-2346 • Hrvoje Jurin, https://orcid.org/0000-0002-2599-553X Jure Samardžić, https://orcid.org/0000-0002-9346-6402 • Jana Ljubas, https://orcid.org/0000-0001-7171-2206 Marijan Pašalić, https://orcid.org/0000-0002-3197-2190 • Daniel Lovrić, https://orcid.org/0000-0002-5052-6559 Fran Borovečki, https://orcid.org/0000-0002-5178-7929 • Maja Čikeš, https://orcid.org/0000-0002-4772-5549 Davor Miličić, https://orcid.org/0000-0001-9101-1570
\end{abstract}

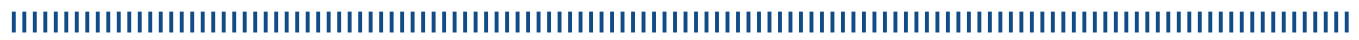

Background: Current guidelines recommend genetic counselling and testing in patients with familial non-ischemic idiopathic cardiomyopathies with hypertrophic, dilated, restrictive or arrhythmogenic phenotype. ${ }^{1,2}$ We aimed to investigate genotype features of patients with non-ischemic cardiomyopathies in advanced stage of heart failure in University Hospital Centre Zagreb.

Methods: Genetic testing (single variant and multiple variant testing) was performed in part using the in-house genetics laboratory, and also in a collaborating genetics laboratory in Helsinki, Finland (Blue-

TABLE 1. Genotypes associated with clinically observed phenotypes.

\begin{tabular}{|c|c|c|c|}
\hline Clinical phenotype & $\mathrm{DCM}(\mathrm{N}=6)$ & $\mathrm{RCM}(\mathrm{N}=6)$ & $\operatorname{ACM}(\mathrm{N}=2)$ \\
\hline Gender (males) & $3 / 6$ & $4 / 6$ & $1 / 2$ \\
\hline Age (years) & $34.6 \pm 11.9$ & $49.9 \pm 14.4$ & $36.9 \pm 12.7$ \\
\hline \multicolumn{4}{|l|}{ Genotype } \\
\hline \multirow[t]{2}{*}{ - pathogenic } & $1 / 6$ & $1 / 6$ & $1 / 6$ \\
\hline & TNNT2 & FLNC & PKP2 \\
\hline \multirow[t]{3}{*}{ - likely pathogenic } & $2 / 6$ & $3 / 6$ & $1 / 6$ \\
\hline & FLNC & TTR & LMNA \\
\hline & DSP & MYH7 & \\
\hline \multirow[t]{4}{*}{ - VUS } & $3 / 6$ & $1 / 6$ & $0 / 6$ \\
\hline & DMD, DES, DYSF, SGCB & KCNA5 & \\
\hline & MYH7, PRDM16 & & \\
\hline & FLNC & & \\
\hline - negative & $0 / 6$ & $1 / 6$ & $0 / 6$ \\
\hline
\end{tabular}

DCM: dilated cardiomyopathy, RCM: restrictive cardiomyopathy, ACM: arrhythmogenic cardiomyopathy, TNNT2: cardiac troponin T, FLNC: filamin C, PKP2: plakophilin 2, TTR: transthyretin, LMNA: Iamin A/C, DSP: desmoplakin, MYH7: myosin heavy chain 7, DMD: dystrophin, DES: desmin, DYSF: dysferlin, SGCB: sarcoglycan beta, KCNA5: potassium voltage-gated channel subfamily A member 5, PRDM16: PR/SET Domain 16, VUS: variant of uncertain significance.

\section{RECEIVED:}

December 3, 2020

ACCEPTED:

December 18, 2020

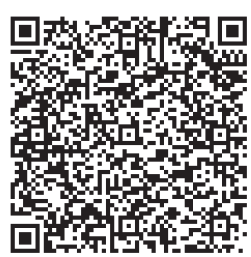

Conclusion: Genetic testing in our advanced heart failure population yields important information on etiology of the diseases, and indicates further family screening.

LITERATURE IIIIIIIIIIIIIIIIIIIIIIIIIIIIIIIIIIIIIIIIIIIIIIIIIIIIIIIIIIIIIIIIIIIIIIIIIIIIIIIIIIIIIIIIIIIIIIIIIII

1. Ponikowski P, Voors AA, Anker SD, Bueno H, Cleland JGF, Coats AJS, et al; ESC Scientific Document Group. 2016 ESC Guidelines for the diagnosis and treatment of acute and chronic heart failure: The Task Force for the diagnosis and treatment of acute and chronic heart failure of the European Society of Cardiology (ESC)Developed with the special contribution of the Heart Failure Association (HFA) of the ESC. Eur Heart J. 2016 Jul 14;37(27):2129-2200. https://doi.org/10.1093/eurheartj/ehw128

2. Hershberger RE, Hedges DJ, Morales A. Dilated cardiomyopathy: the complexity of a diverse genetic architecture. Nat Rev Cardiol. 2013 Sep:10(9):531-47. https://doi.org/10.1038/nrcardio.2013.105 